\title{
The Stereochemical Course of the Reaction Catalyzed by RimO, a Radical SAM Methylthiotransferase
}

\author{
Bradley J. Landgraf ${ }^{1}$ \& Squire J. Booker ${ }^{1,2,3}$ \\ ${ }^{1}$ Department of Chemistry, ${ }^{2}$ Department of Biochemistry and Molecular Biology, and ${ }^{3}$ The Howard Hughes \\ Medical Institute, The Pennsylvania State University, University Park, Pennsylvania 16802, United States
}

\section{SUPPORTING INFORMATION}

\section{EXPERIMENTAL PROCEDURES}

Cloning and Overexpression of the Ec aspA gene and purification of Ec AspA. The Ec aspA gene was amplified from Ec genomic DNA using polymerase chain reaction (PCR) technology. The forward amplification primer (5'- CGC GGC GTC CAT ATG TCA AAC AAC ATT CGT ATC GAA GAA GAT CTG TTG G -3') included an NdeI restriction site (underlined) flanked by a nine-base GC clamp and the first 34 bases of the aspA gene. The reverse primer (5'- CGC GGC GTC CTC GAG TTA CTG TTC GCT TTC ATC AGT ATA GCG TTT TGC-3') contained a XhoI restriction site (underlined) flanked by a nine-base GC clamp and the last 33 bases of the aspA gene, including the stop codon. The PCR was performed with a Stratagene Robocycler thermocycler (La Jolla, CA) as described previously. ${ }^{1}$ The product was isolated and digested with $N d e \mathrm{I}$ and $\mathrm{XhoI}$ and ligated into similarly digested pET-28a by standard procedures. The correct construct, encoding a 10 amino acid linker between the gene product and an $\mathrm{N}$-terminal hexahistidine tag, was verified by DNA sequencing and designated $\mathrm{pEcAspA}$.

Expression vector pEcAspA was transformed into Ec BL21(DE3) for gene expression. Bacterial growth and gene expression was carried out at $37{ }^{\circ} \mathrm{C}$ in $8 \mathrm{~L}$ of Luria-Bertani media distributed evenly among 4 Erlenmeyer flasks with moderate shaking (180 rpm). At an optical density at $600 \mathrm{~nm}$ of 0.6 , a sterile solution of IPTG was added to each flask to a final concentration of $200 \mu \mathrm{M}$. Expression was allowed to take place for $5 \mathrm{~h}$ at $37{ }^{\circ} \mathrm{C}$ before the cells were harvested by centrifugation at $10,000 \times \mathrm{g}$ for $10 \mathrm{~min}$ at ambient temperature.

Purification of Ec AspA was carried out by immobilized metal affinity chromatography (IMAC) using Ni-NTA resin at $4^{\circ} \mathrm{C}$ (Qiagen, Valencia, CA). Buffers used during the purification of $E c$ AspA were as follows: lysis buffer (50 mM HEPES, pH 7.5, $300 \mathrm{mM} \mathrm{KCl}, 10$ $\mathrm{mM}$ 2-mercaptoethanol, $20 \mathrm{mM}$ imidazole, and $1 \mathrm{mg} / \mathrm{mL}$ lysozyme); wash buffer (50 $\mathrm{mM}$ HEPES, pH 7.5, $300 \mathrm{mM} \mathrm{KCl}, 10 \mathrm{mM}$ 2-mercaptoethanol, 10\% (v/v) glycerol, and $40 \mathrm{mM}$ imidazole); elution buffer (wash buffer containing $250 \mathrm{mM}$ imidazole). After lysing the cells by sonication, the cell suspension was transferred into sterile centrifuge tubes, which were subsequently subjected to centrifugation at $50,000 \times \mathrm{g}$ at $4^{\circ} \mathrm{C}$ for $1 \mathrm{~h}$. The supernatant was loaded onto Ni-NTA resin, which was subsequently washed with $120 \mathrm{~mL}$ of wash buffer. After addition of elution buffer to the column, protein-containing fractions, as determined by UV-Vis 
spectrophotometric analysis at $280 \mathrm{~nm}$ on a Cary 50 spectrophotometer (Varian, Walnut Creek, CA), were pooled and concentrated using an Amicon stirred ultrafiltration apparatus (Millipore, Billerica, MA) fitted with a YM-30 membrane (30,000 molecular weight cutoff). The protein was exchanged into gel-filtration buffer (GFB) (50 mM potassium phosphate, $\mathrm{pH} 8,10 \%$ glycerol, using a Sephadex G-25 column $(2.5 \times 13 \mathrm{~cm})$, concentrated again and stored in aliquots at $-80^{\circ} \mathrm{C}$ until ready for use.

Chemoenzymatic syntheses of $(2 S, 3 R)-3-\left[{ }^{2} \mathrm{H}_{1}\right]$ aspartic acid (pro-R) and $(2 S, 3 S)-\left[2,3-{ }^{2} \mathrm{H}_{2}\right]$ aspartic acid (pro-S) and their incorporation into synthetic S12 13-mer peptide substrates. $(2 S, 3 R)-3-\left[{ }^{2} \mathrm{H}_{1}\right]$ aspartic acid (pro- $R$ ) and $(2 S, 3 S)-\left[2,3-{ }^{2} \mathrm{H}_{2}\right]$ aspartic acid (pro-S) were prepared as previously described by Young and colleagues ${ }^{2}$ and Richards and colleagues. ${ }^{3}$ After crystallization of the labeled aspartic acids, each was chemically activated for solid phase peptide synthesis using standard Fmoc and t-butyl protection strategies for the amino and $\beta$-carboxylic acid moieties of aspartic acid, respectively. Each labeled aspartic acid was added to a thickwalled glass bottle containing dioxane in which 2-fold molar excess para-toluenesulfonic acid had been dissolved. The bottle was placed in an ice bath and stirred. 2-methylpropene (isobutylene) was condensed in a flask placed in a dry ice/acetone bath and was quickly added to the glass bottle, tightly capped, and allowed to react with vigorous stirring for $72 \mathrm{~h}$ at room temperature. The cap was carefully removed, and the reaction was vigorously stirred and gently heated to evolve excess isobutylene gas. Once isobutylene bubbles were no longer observed $(\sim 3$ h), the solution was titrated to $\mathrm{pH} 10$ with $10 \%$ sodium carbonate and placed in an ice bath. Fmoc $N$-hydroxysuccinimide ester (Fmoc-OSu) (AnaSpec, Inc. Fremont, CA), in 3-fold molar excess of the labeled aspartic acid, was dissolved in dioxane and added dropwise to the mixture, stirred for $1 \mathrm{~h}$ on ice, and then allowed to react overnight while stirring at room temperature. The next day the reaction was poured into an equal volume of ice water and then extracted with diethyl ether to remove unreacted Fmoc-OSu. The aqueous fraction was slowly acidified to $\mathrm{pH} 2$ with $6 \mathrm{M} \mathrm{HCl}$, vigorously stirred to promote evolution of $\mathrm{CO}_{2}$, and subsequently extracted 3 times with ethyl acetate. The ethyl acetate extractions were combined and dried over $\mathrm{MgSO}_{4}$, filtered, and concentrated in vacuo to yield a thick, yellow syrup, which contained a mixture of the labeled Fmoc- $N$-aspartic acid and the desired labeled Fmoc- $N$-aspartic acid $\beta$-tert-butyl ester. This mixture was dissolved in 3:1 0.1\% TFA, 60\% methanol:acetonitrile, placed on ice, and allowed to crystallize to yield the desired $(2 \mathrm{~S}, 3 \mathrm{R})-3-\left[{ }^{2} \mathrm{H}_{1}\right]$ Fmoc- $N$-aspartic acid $\beta$-tert-butyl ester or $(2 \mathrm{~S}, 3 \mathrm{~S})-\left[2,3-{ }^{2} \mathrm{H}_{2}\right]$ Fmoc- $N$-aspartic acid $\beta$-tert-butyl ester. NMR analysis to confirm the identity of each compound and retention of the deuterium label was conducted on a Bruker Avance III HD 500.20 MHz spectrometer equipped with a $5 \mathrm{~mm}$ Prodigy BBO z-gradient probe. NMR spectral acquisition parameters were as follows: 32 scans, 1 second relaxation delay, $3.3 \mathrm{~s}$ acquisition time, and 64k points. NMR spectra were processed with MNova software (MestreLab Research, S.L., Santiago, Spain) with the following functions: Exponential: 1.6 Hz; Gaussian: $1.10 \mathrm{~Hz}$; TRAF: $0.2 \mathrm{~Hz}$. 


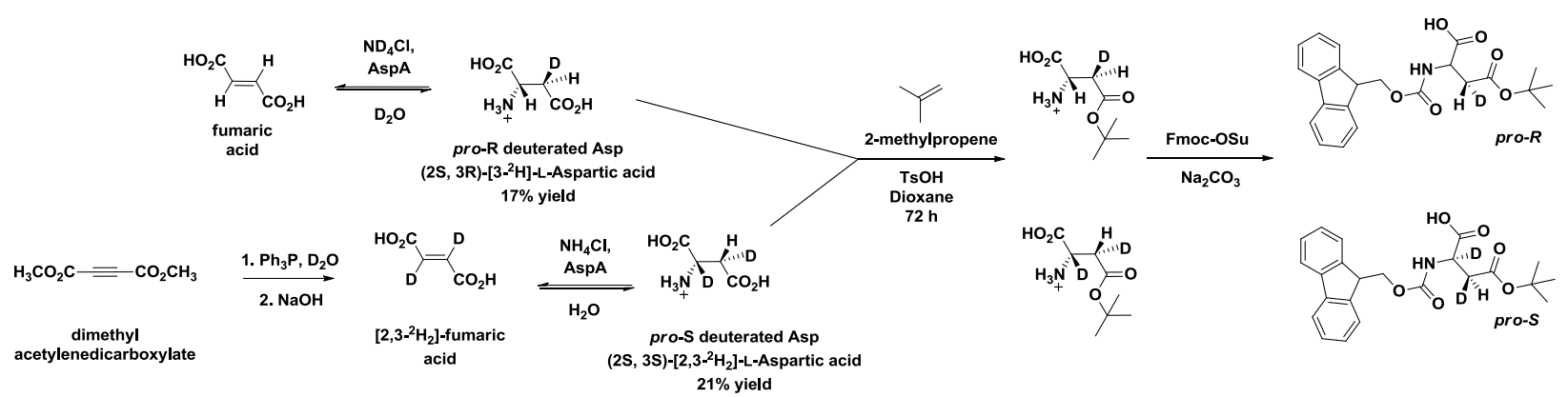

Scheme 1. Synthetic routes for $(2 \mathrm{~S}, 3 \mathrm{R})-3-\left[{ }^{2} \mathrm{H}_{1}\right]$ Fmoc- $N$-aspartic acid $\beta$-tert-butyl ester and (2S,3S)-[2,3- $\left.{ }^{2} \mathrm{H}_{2}\right]$ Fmoc- $N$-aspartic acid $\beta$-tert-butyl ester. 


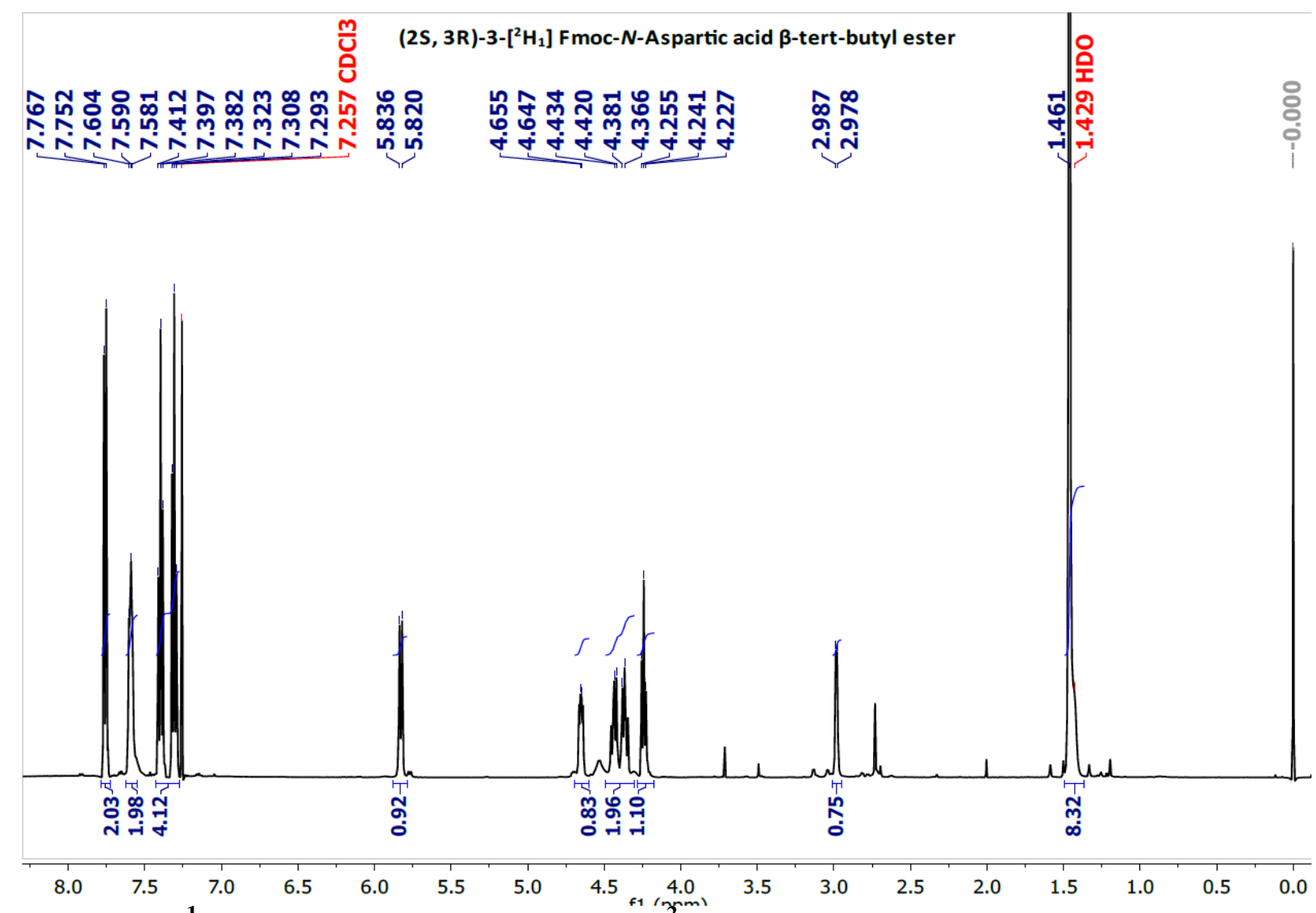

SI Figure 1. ${ }^{1} \mathrm{H}$ NMR spectrum of (2S, 3R)-3-[ $\left.{ }^{2} \mathbf{H}_{1}\right]$ Fmoc- $N$-aspartic acid $\beta$-tert-butyl ester (pro-R 3- $\left[{ }^{2} \mathbf{H}_{1}\right]$-aspartate)

(2S, 3R)-3- $\left[{ }^{2} \mathbf{H}_{1}\right]$ Fmoc- $N$-aspartic acid $\beta$-tert-butyl ester: ${ }^{1} \mathrm{H}$ NMR $(500 \mathrm{MHz}$, chloroform- $d$ ) $\delta 7.76(\mathrm{~d}, J=7.5 \mathrm{~Hz}, 2 \mathrm{H}), 7.59(\mathrm{t}, J=5.6 \mathrm{~Hz}, 2 \mathrm{H}), 7.35(\mathrm{dt}, J=44.7,7.5 \mathrm{~Hz}, 4 \mathrm{H}), 5.83(\mathrm{~d}, J=$ $8.5 \mathrm{~Hz}, 1 \mathrm{H}), 4.65(\mathrm{dd}, J=8.6,4.5 \mathrm{~Hz}, 1 \mathrm{H}), 4.49-4.30(\mathrm{~m}, 2 \mathrm{H}), 4.24(\mathrm{t}, J=7.1 \mathrm{~Hz}, 1 \mathrm{H}), 2.98(\mathrm{~d}$, $J=4.4 \mathrm{~Hz}, 1 \mathrm{H}), 1.46(\mathrm{~s}, 9 \mathrm{H})$. 


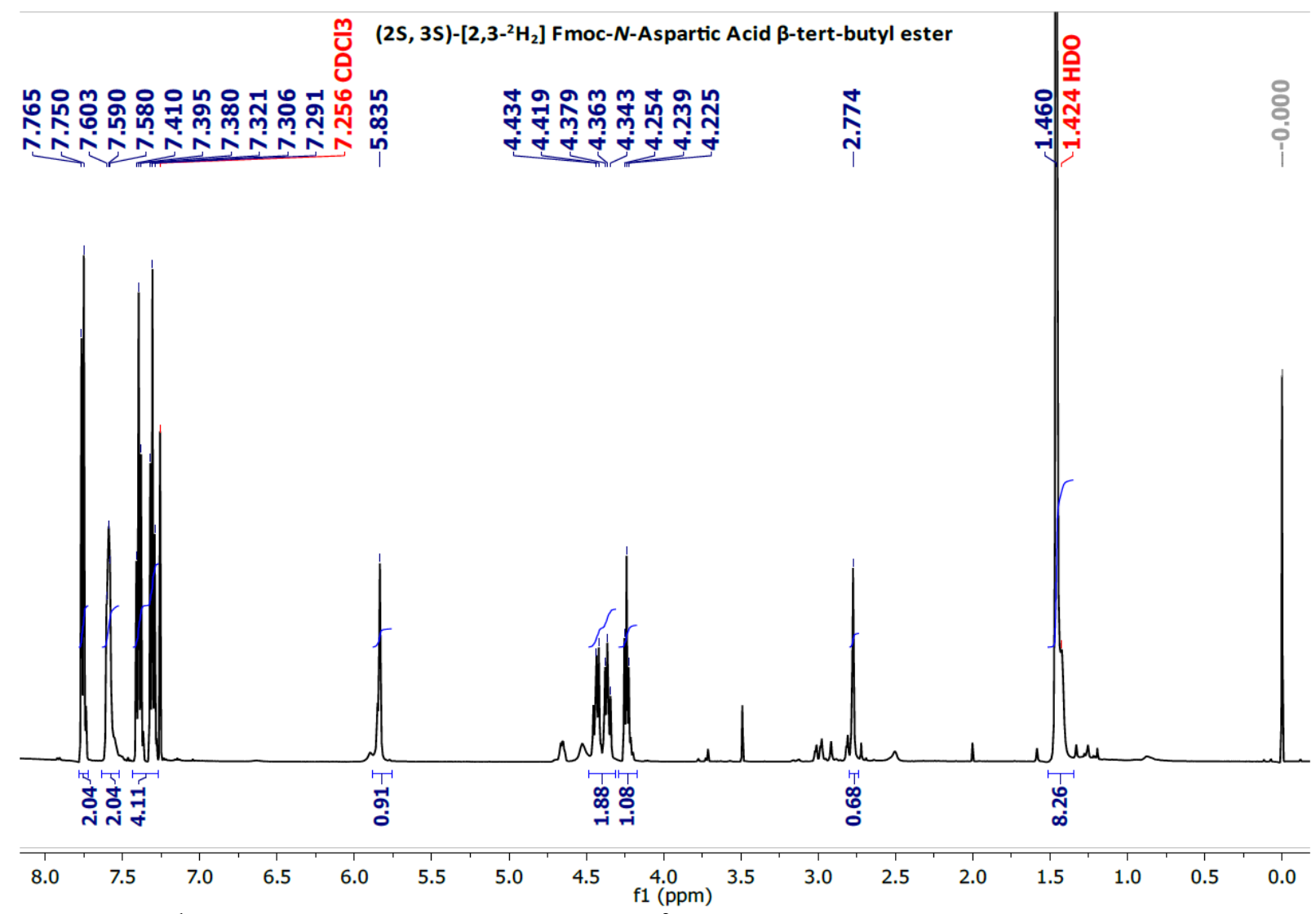

SI Figure 2. ${ }^{1} \mathrm{H}$ NMR spectrum of (2S, 3R)-3- $\left[{ }^{2} \mathbf{H}_{1}\right]$ Fmoc- $\boldsymbol{N}$-aspartic acid $\beta$-tert-butyl ester (pro-S 2,3-[ $\left[\mathrm{H}_{1}\right]$-aspartate)

(2S, 3S)-[2,3- $\left.{ }^{2} \mathbf{H}_{2}\right]$ Fmoc- $\boldsymbol{N}$-aspartic acid $\boldsymbol{\beta}$-tert-butyl ester: ${ }^{1} \mathrm{H}$ NMR $(500 \mathrm{MHz}$, chloroformd) $\delta 7.76(\mathrm{~d}, J=7.5 \mathrm{~Hz}, 2 \mathrm{H}), 7.59(\mathrm{t}, J=5.7 \mathrm{~Hz}, 2 \mathrm{H}), 7.35(\mathrm{dt}, J=44.4,7.4 \mathrm{~Hz}, 4 \mathrm{H}), 5.84(\mathrm{~s}$, $1 \mathrm{H}), 4.48-4.31(\mathrm{~m}, 2 \mathrm{H}), 4.24(\mathrm{t}, J=7.1 \mathrm{~Hz}, 1 \mathrm{H}), 2.77(\mathrm{~s}, 1 \mathrm{H}), 1.46(\mathrm{~s}, 9 \mathrm{H})$. 

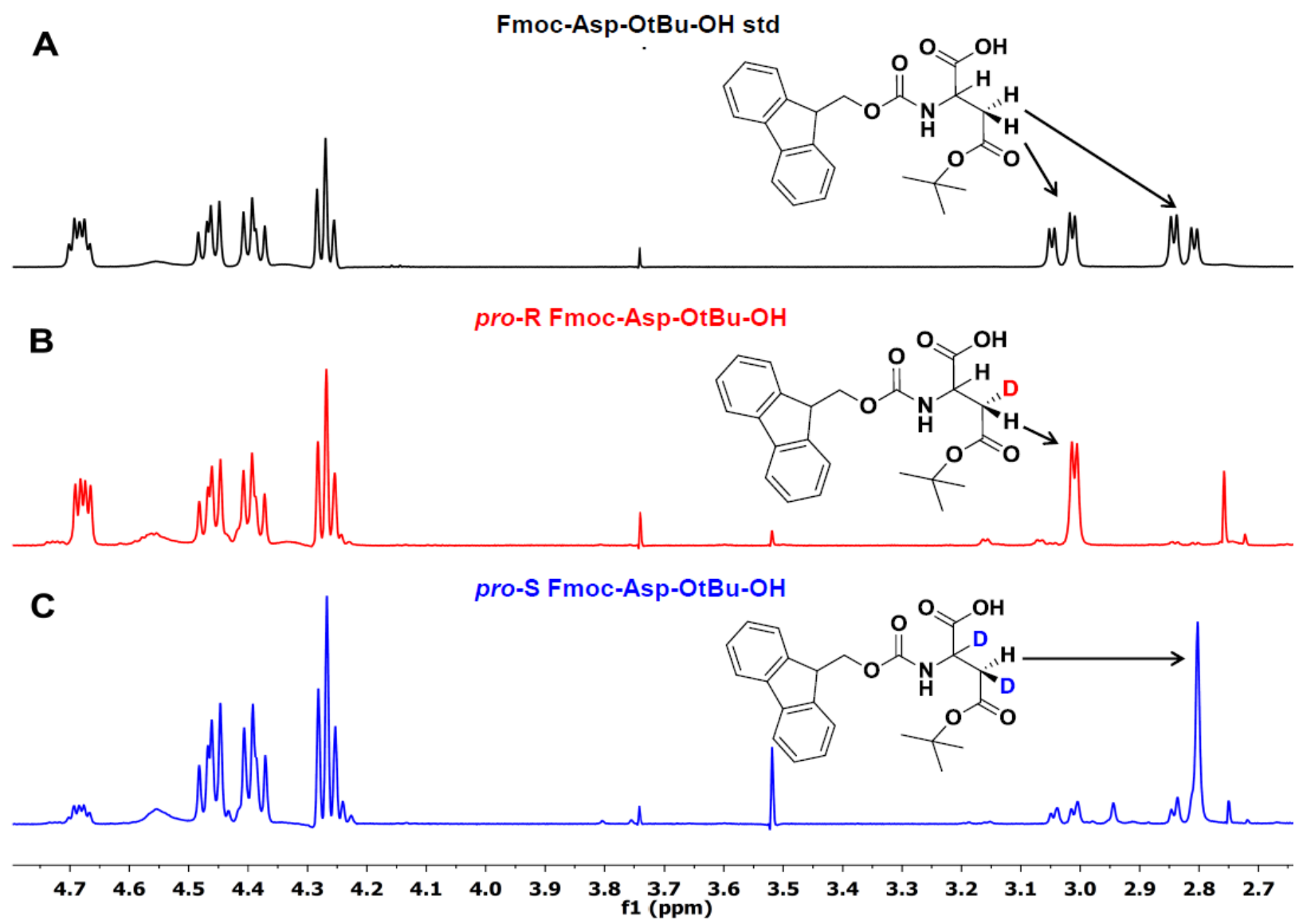

SI Figure 3. Stacked ${ }^{1} \mathrm{H}$ NMR spectra from 2.7 - 4.7 ppm of Fmoc- $N$-aspartic acid $\beta$-tert-butyl ester standard (A), (2S,3R)-3- $\left[{ }^{2} \mathrm{H}_{1}\right]$ Fmoc- $N$-aspartic acid $\beta$-tert-butyl ester $(\mathbf{B})$, and (2S,3S)-[2,3${ }^{2} \mathrm{H}_{2}$ ] Fmoc- $N$-aspartic acid $\beta$-tert-butyl ester $(\mathbf{C})$.

Following NMR confirmation of the desired deuterium-labeled aspartates, each compound was incorporated into a synthetic peptide by the Penn State Hershey College of Medicine Macro Core Facility. The peptides consisted of 13 amino acids $\left(\mathrm{NH}_{2}-\mathrm{RGGRVKDLLGVRY-COOH}\right)$ corresponding to residues 83-95 of the Bacteroides thetaiotaomicron S12 ribosomal protein, in which $\underline{\mathbf{D}}$ denotes the pro- $R$ - or pro-S-labeled aspartic acid. Hereafter these peptides are referred to as $\mathbf{2}$ and $\mathbf{3}$, respectively. MALDI-TOF analysis of the crude peptides was used to verify the target peptide mass and retention of their respective deuterium labeling. $\mathbf{2}$ and $\mathbf{3}$ were then purified on an Agilent 1100 series high-performance liquid chromatography (HPLC) system (Agilent Technologies, Santa Clara, CA) using a ZORBAX SB-C18 $9.4 \mathrm{~mm} \times 25 \mathrm{~cm}$ semi-prep column (Agilent, Santa Clara, CA) with $0.1 \%$ trifluoroacetic acid (solvent A) and acetonitrile (solvent B) flowing at $4 \mathrm{~mL} / \mathrm{min}$ with UV-vis detection at $275 \mathrm{~nm}$. The column was equilibrated in $100 \%$ solvent A. After sample injection, the following gradient was applied: $25 \%$ solvent B 
(0-10 min), 30\% solvent B (10-15 min), 100\% solvent B (15-20 min), 0\% solvent B (20-25 min). The target peptides eluted at 12.6 min and were collected, analyzed by ESI ${ }^{+} \mathrm{LC} / \mathrm{MS}$ to confirm their identities, lyophilized, resuspended in anaerobic $18 \mathrm{M} \Omega$ water, titrated to $\mathrm{pH} 7$ with $\mathrm{NaOH}$, and flash frozen in liquid $\mathrm{N}_{2}$ until use.

Cloning and Overexpression of the Bt rimO gene and purification of Bt RimO. A plasmid (pSGC-His) encoding an N-terminally hexahistidine-tagged form of Bt RimO containing a 15 amino acid linker (SSGVDLGTENLYFQS) was a gift from Dr. Steven Almo at the Albert Einstein College of Medicine. The plasmid DNA was extracted and purified from cells using a NucleoSpin Plasmid kit (Macherey-Nagel, Düren, Germany), and its sequence was verified before its transformation into Ec BL21 (DE3) cells containing the pDB1282 plasmid as previously described. ${ }^{4}$ Bacterial growth, gene expression, purification, and reconstitution of $B t$ RimO was carried out as previously described for Thermotoga maritima RimO, with the omission of the heat denaturation of native $E c$ proteins. ${ }^{5}$ Typical protein yields following IMAC was $\sim 6.5 \mathrm{mg} / \mathrm{L}$ of cell culture and after reconstitution and purification by size exclusion chromatography was $\sim 1.5 \mathrm{mg} / \mathrm{L}$ of cell culture. Purity was estimated to be greater than $90 \%$.

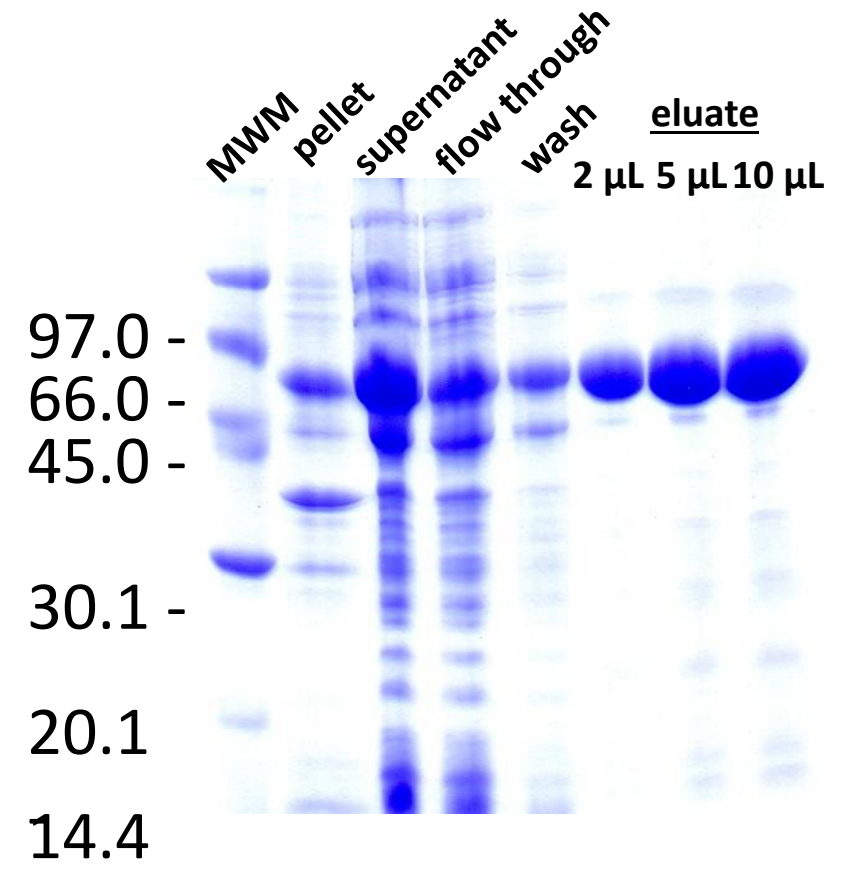

SI Figure 4. SDS-PAGE of IMAC (Ni-NTA) purification of pSC-His $B t$ RimO 


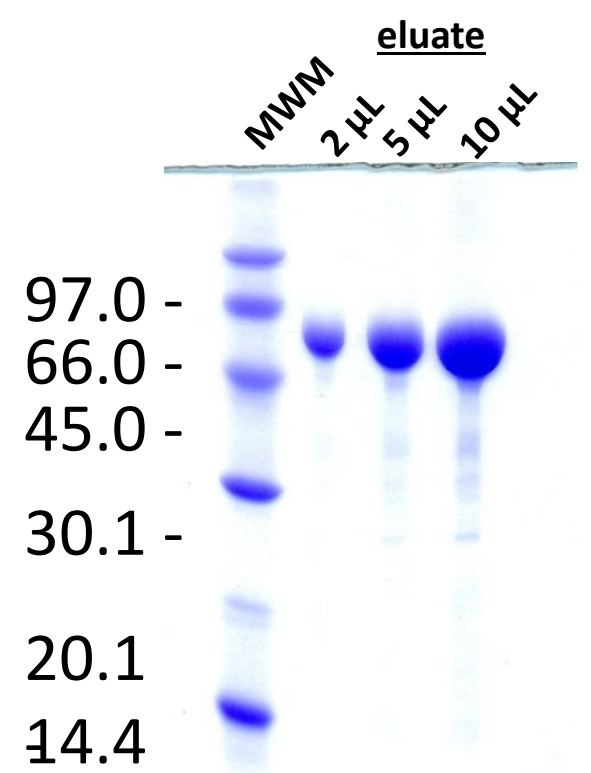

SI Figure 5. SDS-PAGE of pSC-His Bt RimO following reconstitution and size exclusion chromatography.

Determination of the stereospecificity of hydrogen atom abstraction by Bt RimO. The pro-R and pro-S labeled peptide substrates were used in reactions with $B t$ RimO to determine which compound afforded deuterium enrichment into 5'-deoxyadenosine (5'-dAH), thereby indicating which hydrogen atom is removed by the 5'-deoxyadenosyl radical. Each Bt RimO reaction contained the following in a final volume of $220 \mu \mathrm{L}$ : $100 \mu \mathrm{M}$ Bt RimO, $3 \mathrm{mM} \mathrm{SAM}, 3 \mathrm{mM} \mathrm{1,2}$, or 3 as substrate, $50 \mathrm{mM}$ Na-HEPES, pH 7.5, and, where appropriate, $200 \mu \mathrm{M} E c$ flavodoxin, 50 $\mu \mathrm{M} E c$ flavodoxin reductase, and $3 \mathrm{mM}$ NADPH. In some instances $2 \mathrm{mM}$ dithionite was used to replace the flavodoxin reducing system. All components except SAM were incubated at $37^{\circ} \mathrm{C}$ for $15 \mathrm{~min}$ before initiating the reaction with the omitted component. Aliquots $(15 \mu \mathrm{L})$ of the reaction mixture were withdrawn at various times from $0-180 \mathrm{~min}$ and added to $15 \mu \mathrm{L}$ of $0.5 \mathrm{M}$ $\mathrm{H}_{2} \mathrm{SO}_{4}$ containing $100 \mu \mathrm{M}$ AtsA peptide $\left(\mathrm{NH}_{2}\right.$-PMSAPARSM-COOH, 4) and $100 \mu \mathrm{M}$ tryptophan as external standards to quench the reaction. Precipitated protein was removed by centrifugation at $18,000 \times \mathrm{g}$ for $15 \mathrm{~min}$, and a $40 \mu \mathrm{L}$ aliquot of the resulting supernatant was subjected to analysis by ESI ${ }^{+}$LC/MS with single-ion monitoring (SIM) as previously described. ${ }^{5}$ Solvent A consisted of ammonium acetate $(40 \mathrm{mM})$ and methanol $(5 \% \mathrm{v} / \mathrm{v})$ titrated to $\mathrm{pH} 6.0$ with acetic acid, while solvent B was $100 \%$ acetonitrile. The column was equilibrated in $100 \%$ solvent $\mathrm{A}$ at a flow rate of $0.5 \mathrm{~mL} \mathrm{~min}^{-1}$. After sample injection $(5 \mu \mathrm{L})$, a gradient was applied from $0 \%$ solvent B to $100 \%$ solvent B over $10 \mathrm{~min}$ and then from $100 \%$ to $0 \%$ over $3 \mathrm{~min}$. The monitored ions $(\mathrm{m} / \mathrm{z})$ and retention times $(\mathrm{min})$, respectively, were 385.1 and $2.7(\mathrm{SAH}), 188.0$ and 3.0 (tryptophan), 252.1 and $3.2\left(5^{\prime}-\mathrm{dAH}\right), 253.1$ and 3.2 (5'-dAD), 474.4 and $3.8(4), 737.1$ and $4.0(\mathbf{1}), 737.6$ and $4.0(\mathbf{2}), 738.1$ and $4.0(3), 760.1$ and 4.1 (methylthiolated peptide, 3-MS- 
1), 760.6 and 4.1 (monodeuterated methylthiolated peptide, 3-MS-2), 761.6 and 4.1 (dideuterated methylthiolated peptide, 3-MS-3). Calibration curves were generated with known concentrations of each analyte and were run under identical conditions to determine the concentration of products generated in assays. Data were analyzed using the Agilent Technologies MassHunter qualitative and quantitative analysis software. For methionine quantification, ESI+ LC/MS with multiple reaction monitoring (MRM) was used. Solvent A consisted of $0.2 \%$ formic acid, while solvent B was $100 \%$ methanol. The column was equilibrated in $97 \%$ solvent $\mathrm{A}, 3 \%$ solvent $\mathrm{B}$ at a flow rate of $0.5 \mathrm{~mL} \mathrm{~min}{ }^{-1}$. After sample injection $(10 \mu \mathrm{L})$, isocratic conditions were maintained from 0 to $4.5 \mathrm{~min}$, a gradient of $3 \%$ solvent B to $90 \%$ solvent B was applied from 4.5 to $6.5 \mathrm{~min}$, and then from $90 \%$ solvent B to $3 \%$ solvent B over $3 \mathrm{~min}$. The monitored transition $(\mathrm{m} / \mathrm{z})$ and retention time ( $\mathrm{min})$ for methionine were 150.1/104.1 and 1.7, respectively.

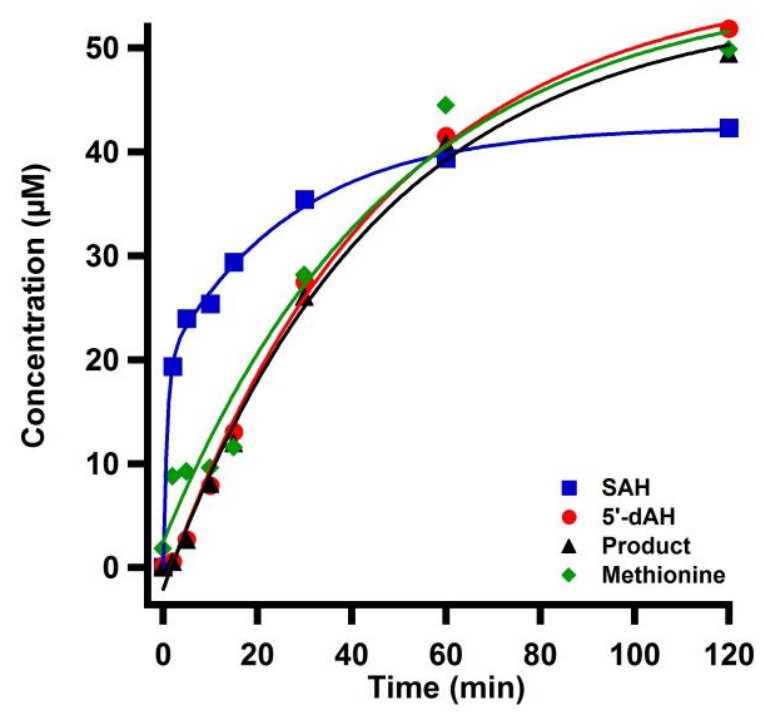

SI Figure 6. Quantification of methionine generated in the $B t$ RimO reaction. The reaction was conducted as described above and contained $150 \mu \mathrm{M} \mathrm{Bt}$ RimO, $1.5 \mathrm{mM}$ SAM, $1.5 \mathrm{mM}$ peptide (1), $150 \mu \mathrm{M} E c$ Fld, $150 \mu \mathrm{M} E c$ FldR, $1 \mathrm{mM}$ NADPH, and $50 \mathrm{mM}$ Na-HEPES pH 7.5. The lines are fits to a first-order exponential equation for 5'-dAH, product, and methionine, and the line for SAH was fit to a second-order exponential equation with the following kinetic parameters: 5'dAH formation: $A=58.8 \pm 2.6 \mu \mathrm{M}, \mathrm{v}=1.1 \pm 0.1 \mu \mathrm{M} \mathrm{min}{ }^{-1}$; product formation: $A=56.4 \pm 2.6$ $\mu \mathrm{M}, \mathrm{v}=1.2 \pm 0.1 \mu \mathrm{M} \mathrm{min}^{-1}$; methionine formation: $A=53.6 \pm 6.5 \mu \mathrm{M}, \mathrm{v}=1.1 \pm 0.1 \mu \mathrm{M} \mathrm{min}^{-1}$; SAH formation: $A_{1}=19.5 \pm 1.7 \mu \mathrm{M}, v_{1}=23.6 \pm 2.0 \mu \mathrm{M} \mathrm{min} \min ^{-1} ; A_{2}=22.9 \pm 1.3 \mu \mathrm{M}, v_{2}=0.8 \pm$ $0.1 \mu \mathrm{M} \mathrm{min}{ }^{-1}$. Methionine is generated stoichiometrically with $5^{\prime}-\mathrm{dAH}$ which indicates that the RimO reaction does not use methionine as a source of sulfur or methylthio group for the methylthiolation reaction. 


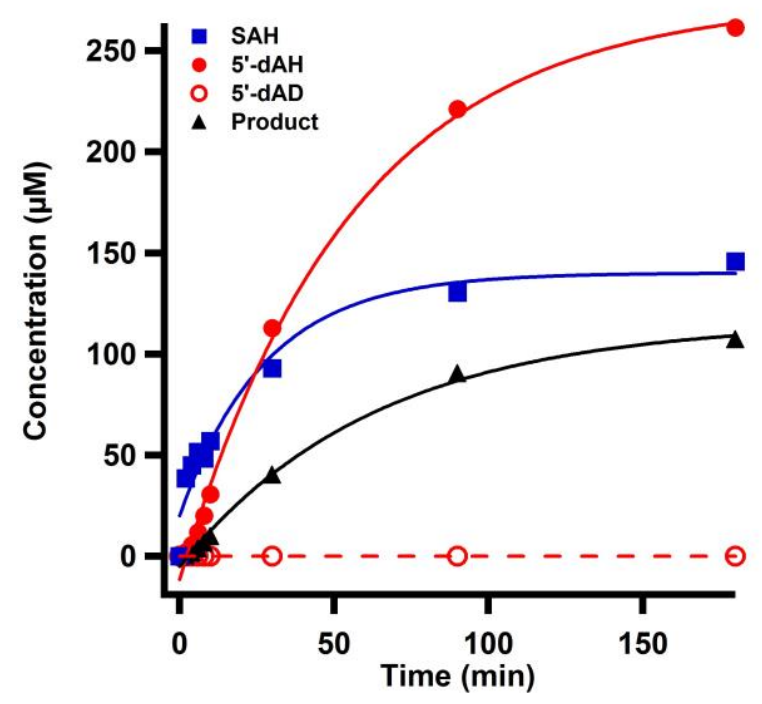

SI Figure 7. Quantification of 5'-dAD generated in the reaction of $B t$ RimO conducted in $90 \%$ $\mathrm{D}_{2} \mathrm{O}$ with unlabeled peptide (1). The reaction was conducted as described above with the following modifications: the peptide (1), NADPH, and Na-HEPES were dissolved in $\mathrm{D}_{2} \mathrm{O}$, lyophilized, and resuspended in $\mathrm{D} 2 \mathrm{O}$; the protein components (Bt RimO, Ec Fld, and Ec FldR) were diluted in $\mathrm{D}_{2} \mathrm{O}$ for two hours on ice prior to the reaction. The reaction mixture contained $100 \mu \mathrm{M}$ Bt RimO, $2 \mathrm{mM}$ SAM, $3 \mathrm{mM}$ peptide (1), $150 \mu \mathrm{M}$ Ec Fld, $37.5 \mu \mathrm{M} E c$ FldR, $2 \mathrm{mM}$ $\mathrm{NADPH}, 50 \mathrm{mM}$ Na-HEPES $\mathrm{pH} 7.5$ in $\mathrm{D}_{2} \mathrm{O}$. The lines are fits to a first-order exponential equation with the following kinetic parameters: $\mathrm{SAH}$ formation: $A=119.9 \pm 10.5 \mu \mathrm{M}, v=4.3 \pm$ $0.4 \mu \mathrm{M} \mathrm{min}$ m $^{-1}$; 5'-dAH formation: $A=286.3 \pm 8.9 \mu \mathrm{M}, v=5.1 \pm 0.2 \mu \mathrm{M} \mathrm{min}{ }^{-1}$; product formation: $A=121.2 \pm 4.8 \mu \mathrm{M}, v=1.9 \pm 0.1 \mu \mathrm{M} \min ^{-1} .5^{\prime}-\mathrm{dAD}$ was not observed above natural abundance, suggesting that any $5^{\prime}-\mathrm{dA} \bullet$ that is formed does not abstract a hydrogen atom from a solvent exchangeable site.

1. Cicchillo, R. M.; Lee, K.-H.; Baleanu-Gogonea, C.; Nesbitt, N. M.; Krebs, C.; Booker, S. J., Biochemistry 2004, 43, 11770.

2. Gani, D.; Young, D. W. J. Chem. Soc., Perk. Trans. 1 1983, 2393.

3. Richards, E. M.; Tebby, J. C.; Ward, R. S.; Williams, D. H. J. Chem Soc. C. 1969, 11, 1542.

4. Lanz, N. D.; Grove, T. L.; Gogonea, C. B.; Lee, K.-H.; Krebs, C.; Booker, S. J. Methods Enzymol. 2012, 516, 125.

5. Landgraf, B. J.; Arcinas, A. J.; Lee, K.-H.; Booker, S. J. J. Am. Chem. Soc. 2013, 135, 15404. 